\title{
Effects of high-fat diets on inflammation and antioxidant status in rats: Comparison between palm olein and olive oil
}

\author{
Youzan Ferdinand Djohan ${ }^{\square}$, Absalome Aké Monde ${ }^{1}$, Massara Camara-Cissé1, Eric Badia 5 , \\ Beatrice Bonafos², Gilles Fouret², Céline Lauret ${ }^{5}$, Anne-Marie Dupuy³, Edith Pinot ${ }^{3}$, \\ Gervais Koffi', Germaine Niamké1, Thibault Sutra³, Sylvie Gaillet ${ }^{2}$, Karen Lambert ${ }^{5}$, \\ Fabrice Raynaud 5 , Nathalie Gayrard 4 , Bernard Jover', Jean Paul Cristol ${ }^{3}$, Charles Coudray² \\ and Christine Feillet-Coudray ${ }^{2}$
}

\begin{abstract}
1 Laboratoire de Biochimie, CHU, Univeristy FélixHouphouët-Boigny, Cocody, Côte d'Ivoire; 2DMEM, INRA, University Montpellier, Montpellier, France; ${ }^{3}$ Laboratoire de Biochimie, CHU-Lapeyronie, Montpellier, France; ${ }^{4}$ EA7288, University Montpellier, Montpellier, France; 5 PhyMedExp, University Montpellier, INSERM U1046, CNRS, UMR 9214, Montpellier, France
\end{abstract}

Palm olein (PO) and olive oil (OO) are widely consumed in the world. PO is considered harmful to health, whereas $\mathrm{OO}$ is considered healthy. This study aims to discover the effects of consumption of these oils on antioxidant status and inflammation that can be beneficial for consumer. This was an experimental study in male wistar rats fed a diet containing $30 \%$ of each oil. Rats had free access to food and water. After being fed for 12 weeks, animals were sacrificed and liver and aortic blood were collected. Plasma was used for the determination of interleukin- 6 and oxidative stress parameters (Superoxide dismutase, Gluthation peroxidase, Thiobarbituric acid reactive substances, Thiol groups and isoprostane). The inflammation and oxidative stress status as well as the expression of several genes/proteins were also analyzed in liver homogenate. No significant differences were observed between $\mathrm{PO}$ and $\mathrm{OO}$ in plasma and liver levels of the studied inflammation and oxidative stress parameters. We noted that the consumption of PO does not promote inflammation and oxidative stress. This study will help the researchers to uncover the critical areas of antioxidant and anti-inflammatory effects of olive oil and palm olein consumption.

Key words: palm olein, olive oil, oxidative stress, inflammation, high fat diet

Received: 18 March, 2021; revised: 21 May, 2021; accepted: 21 May, 2021; available on-line: 06 October, 2021

⿶e-mail: djohanferdinand@gmail.com

Acknowledgement of financial support: This work was supported by a research grant from SANIA No. 2015/UM/150666

Abbreviations: $\mathrm{AU}$, arbitrary Unit; CD68, Cluster of differentiation 68; GCLC, Glutamate-cysteine ligase catalytic subunit; GPx, Glutathione peroxidase; GSH, Reduced glutathione; GSSG, Oxidized glutathione; HFD, High fat diet; HO-1, Heme oxygenase-1; Ikb-a, Inhibitor of kappa B-alpha; IL-1b, Interleukin-1b; IL-6, Interleukin-6 $\mathrm{Nf}-\mathrm{kb}$, Nuclear factor-kappa B Nrf2 (Nfe2l2), Nuclear factor-erythroid 2 related factor $2 ; \mathrm{NQO}-1, \mathrm{NAD}(\mathrm{P}) \mathrm{H}$ quinone dehydrogenase 1: $\mathrm{qPCR}$, Quantitative-Polymerase chain reaction; $\mathrm{PO}$, Palm olein; PUFA, Polyunsaturated fatty acids; SOD, Superoxide dismutase; TBARS, Thiobarbituric acid reactive substances; ww, Wet weight

\section{INTRODUCTION}

Palm oil is the most produced (USAD, 2021) and consumed vegetable oil in the world (USAD, 2021). Although crude palm oil is known for its nutritional ben- efits (Edem, 2002; Ong \& Goh, 2002; Sen et al., 2007), industry prefers deodorised and decoloured palm oil for which refining is mandatory. This refining can be based on chemical methods (treatment with alkalis or acids) (Cmolik \& Pokorny, 2000; Dunford, 2012) or physical methods (steam refining, inert gas stripping, molecular distillation, etc.) (Dunford, 2012). This is followed by bleaching and deodorisation steps as well as other specific treatments depending on the first refining process applied. After refining, the product obtained will undergo fractionation to give derived fractions : palm olein or super-olein (a colourless, bland and stable oil, rich in oleic acid) and palm stearin (a fat, rich in saturated fatty acids) (Dunford, 2012; Lecerf, 2013). Refining results in a significant loss of carotenoids and a moderate loss of vitamin E (Tarmizi \& Lin, 2008).

Palm olein is widely used in African, South American and Asian cuisines. Instead of partially hydrogenated oils that contain trans fatty acids, palm stearin is widely used by the food industry in the manufacture of many products such as sweets, cakes, cheese analogues, crisps, chocolates, confectionary fats, biscuits, doughnuts, frozen meals and products (pancakes, pies, pizzas, potatoes, etc.), instant meals, etc. (Mancini et al., 2015; Mba et al., 2015).

Olive oil (OO) is a vegetable oil known to be rich in polyphenols (Owen et al., 2000). Numerous studies report the nutritional benefits of OO polyphenols (PerezJimenez et al., 2005; Covas et al., 2006; Assy et al., 2009). PO, although naturally rich in phytonutrients (vitamin E, Coenzyme Q, etc.) considered beneficial for human health especially for their antioxidant properties $(\mathrm{Ng}$ et al., 2012; Tiahou et al., 2004; Rooyen et al., 2008), is due to its high content of saturated fatty acids (50\%) especially palmitic acid, accused of being potentially harmful to health (Fattore et al., 2014; Odia et al., 2015). Given this, it seemed appropriate to undertake this study to compare the effects of consuming diets rich in $\mathrm{PO}$ and $\mathrm{OO}$ on inflammation and antioxidant status in rats.

\section{MATERIELS AND METHODS}

\section{Animals and diets}

A total of twenty-four young male Wistar rats (Charles River, L'Arbresle, France) aged 6 weeks were used in the 
present study. The rats were housed, two per cage, under conditions of constant temperature $\left(20-22^{\circ} \mathrm{C}\right)$, humidity (45-50\%), and a standard dark cycle (20.00-08.00 hours). The rats were randomised into four groups of eight animals and fed for 12 weeks with one of the following semi-purified diets: (1) control diet (Control), containing $5 \%$ lipid as soybean oil (11\% energy from fat) this is sham control group, (2) high-fat diet (HFD) $(55 \%$ energy from fat) rich in PO with $2.5 \%$ soybean oil and 30\% PO or (3) HFD rich in OO with $2.5 \%$ soybean oil and 30\% OO. PO was supplied by SANIA company (Côte d'Ivoire), and OO (virgin) was bought in a supermarket (these oils were chosen for their large current consumption). The detailed composition of these experimental diets is shown in Table 1. Rats were given free access to water and food during the whole experiment and body growth was determined weekly. Our institution guidelines for the care and use of laboratory animals were followed, and all the experimental procedures were approved by the local ethical committee in Montpellier, France (Reference CEEA-LR-12002).

\section{Rat sacrifice and sampling}

Blood was obtained from $16 \mathrm{~h}$ fasted rats anaesthetised with pentobarbital (Ceva Sante Animale, Libourne, France) by puncturing the abdominal vein with a heparinised syringe (Sodium heparinate, Panpharma SA Fougeres, France). Blood was then distributed into a dry tube $(3-4 \mathrm{ml})$ and a heparinised tube $(5-6 \mathrm{ml})$, centrifuged at $1000 \times g$ for $10 \mathrm{~min}$ at $4^{\circ} \mathrm{C}$, and serum and plasma were collected and stored at $-80^{\circ} \mathrm{C}$ until analysis. The liver was perfused with $10 \mathrm{ml}$ of $0.9 \% \mathrm{NaCl}$ solution, quickly removed, weighed, and cut into different parts. One part was immediately frozen in liquid nitrogen and then kept at $-80^{\circ} \mathrm{C}$ until analysis. Another part was fixed in $10 \%$ neutral buffered formalin and embedded in paraffin for histological analysis.

\section{Inflammation and oxidative stress parameters in blood}

Plasma interleukin-6 (IL-6) levels were quantified with ELISA kits (Fisher Scientific, France). The activity of an-

Table 1. Diet composition $(\mathrm{g} / \mathrm{kg})$ on the basis of the AIN-93M diet formulation.

\begin{tabular}{lccc}
\hline Ingredients & Control & Palm Olein & Olive Oil \\
\hline Casein & 165 & 200 & 200 \\
\hline Cornstarch & 443 & 234 & 234 \\
\hline Maltodextrine & 144 & 80 & 80 \\
\hline Sucrose & 100 & 53 & 53 \\
\hline Soybean oil & 50 & 25 & 25 \\
\hline Palm olein & 0 & 300 & 0 \\
\hline Olive oil & 0 & 0 & 300 \\
\hline Cellulose & 50 & 50 & 50 \\
\hline Mineral mix (AIN-93M) & 35 & 42 & 42 \\
\hline Vitamin mix (AIN-93M) & 10 & 12 & 12 \\
\hline L-Cystine & 2 & 2.4 & 2.4 \\
\hline Choline chloride & 1.5 & 1.8 & 1.8 \\
\hdashline TOTAL & 1000 & 1000 & 1000 \\
\hline
\end{tabular}

tioxidant enzymes has been determined by spectrophotometric methods. Glutathione peroxidase (GPx) activity and total superoxide dismutase (SOD) were measured in blood according to the method of Flohe \& Gunzler (1984) and Marklund (1976), respectively. Thiobarbituric acid-reactive substances (TBARS), was measured according to the method of Sunderman et al., (1985). Protein oxidation was assessed by measurement of sulfhydryl groups (Faure \& Lafond, 1995) in plasma.

Plasma $15-\mathrm{F}_{2 \mathrm{t}}$-isoprotanes, the more specific lipid peroxidation parameter, was also measured by mass spectrometry as described by Mas and others (Mas et al., 2008). Briefly, aliquots of plasma samples were added with $15-\mathrm{F}_{2 \mathrm{t}}$-isoprostane $\mathrm{D} 4$ as an internal standard before extraction using an Agilent Bond Elut Certify II cartridges. Washes were performed with methanol 50\% and ethyl acetate/hexane $(1 / 3 \mathrm{v} / \mathrm{v})$ and elution was performed with ethyl acetate/methanol $(9 / 1 \mathrm{v} / \mathrm{v})$. After esterification, samples were analyzed on a ThermoFinnigan Trace DSQ II interfaced with a Trace GC Ultra 2000 gas chromatograph, equipped with an AS 3000 automatic sampler (ThermoFinnigan).

\section{Liver macrophage identification}

Liver samples were fixed in a neutral $10 \%$ formalin buffer and then embedded in paraffin. Sections of $5 \mu \mathrm{m}$ were made with a microtome (Leïca RM 2145, Microsystems Nussloch GmbH, Germany). After staining with haematoxylin, macrophage infiltrations were detected by immuno-labelling with an anti - cluster of differentiation 68 (anti-CD68) antibody (Bio-Rad, France). Antibody distribution was visualized by a Vecstatin ${ }^{\circledR} \mathrm{ABC}$ kit and an ImmPACT AEC substrate kit (Clinisciences, France). For CD68 determination, 10-20 fields per sample were analyzed and results were expressed as the average percentage of surface with positive staining to total surface of the field.

\section{Inflammation and oxidative stress parameters in liver}

Liver homogenates and supernatants from frozen liver were prepared as described by Coudray and others (Coudray et al., 2016). Supernatant protein level was measured by Bradford's technique (Bradford, 1976). TBARS, thiol groups, reduced glutathione $(\mathrm{GSH})$, oxidised glutathione (GSSG) levels and GPx, SOD and catalase activities were measured by spectrophotometric techniques as described previously (Djohan et al., 2019). In addition, the gene expression of $\mathrm{Nrf} 2$, and some inflammation genes (NF-kB, IkB-a, IL-1 $\beta$ ), and antioxidant genes (NQO-1, HO-1, GCLC) was also assessed (see Liver mRNA expression section).

\section{Liver mRNA expression}

Real-time quantitative PCR was used to measure the mRNA expression of the target genes in the tissues and was performed as described previously (Djohan et al., 2019). The primer sequences used for real-time PCR are shown in the Supplemental Table (at https://ojs.ptbioch.edu.pl/index.php/abp/). Results were normalized to RPLPO gene and were expressed as a percentage of the control. Liver genes analyzed include GCLC, HO-1, I $x$ B- $a$, IL-1 $\beta, N F-x B, N Q O-1, N r f 2$.

\section{Statistical analysis}

Results were expressed as mean and standard deviations, $n=7-8$ animals per group. Statistical analysis was based on one-way ANOVA followed by a Tukey Kram- 
Table 2. Blood and liver inflammation parameters

Rats were fed their respective diet for 12 weeks. Results were expressed as mean values \pm S.D., $n=7-8$ animals per group. Statistical analysis was based on one-way ANOVA followed by a Tukey Kramer multiple comparisons test. The limit of statistical significance was set at $p<0.05$. The group mean values with different letters $(a, b, c)$ are significantly different.

\begin{tabular}{|c|c|c|c|c|}
\hline & Control & $\mathrm{PO}$ & $\mathrm{OO}$ & $p$ \\
\hline \multicolumn{5}{|l|}{ Plasma } \\
\hline IL-6(pg/mL) & $14.67 \pm 2.7$ & $13.98 \pm 2.6$ & $14.48 \pm 4.1$ & NS \\
\hline \multicolumn{5}{|l|}{ Liver } \\
\hline$N F-k B(\mathrm{qPCR})$ & $1.00 \pm 0.07$ & $0.96 \pm 0.04$ & $1.07 \pm 0.02$ & NS \\
\hline IkB-a (qPCR) & $1.00 \pm 0.12^{\mathrm{a}}$ & $1.78 \pm 0.23^{b}$ & $1.33 \pm 0.15^{\mathrm{ab}}$ & 0.027 \\
\hline$I L-1 \beta$ (qPCR) & $1.00 \pm 0.12$ & $0.92 \pm 0.07$ & $1.00 \pm 0.05$ & NS \\
\hline
\end{tabular}

Ikb-a, Inhibitor of kappa B-alpha; II-1b, Interleukin-1b; II-6, Interleukin-6; Nf-kb, Nuclear factor-kappa B; qPCR, Quantitative-Polymerase chain reaction; OO, Olive oil; PO, palm olein

er multiple comparisons test. When statistical variances were unequal, a Welch test was performed. The limit of statistical significance was set at $p<0.05$. The group mean values with different letters $(\mathrm{a}, \mathrm{b}, \mathrm{c})$ are significantly different. Statistical analyses were performed using the StatView program (SAS Institute, Cary, NC, USA).

\section{RESULTS AND DISCUSSION}

\section{Effects of diet on inflammation}

With regard to the inflammatory parameters studied (plasma IL-6, liver IL-1 $\beta, N F-k B$ and $I k B-a$ genes), no diet promoted inflammation (Table 2). In liver, PO diet promoted a significant increase $(p=0.027)$ in the gene expression of $I k B-a(+78 \%)$, compared to the control diet. $\mathrm{OO}$ diet has favoured a non-significant increase in the gene expression of IkB-a (+33\%) compared to the control diet. The gene expression of $N F-k B$ was decreased by $4 \%$ with PO diet and increased by $7 \%$ with $\mathrm{OO}$ diet compared to the control diet. On the other hand, OO diet induced a significant increase $(p<0.0001)$ of macrophage density $(+31 \%$ at least) in rat liver compared to PO and control diets. PO diet induced a significant decrease $(p<0.0001)$ in macrophage density $(-36 \%$ at least $)$ in rat liver compared to $\mathrm{OO}$ and control diets (Table 2).

$\mathrm{NF}-x \mathrm{~B}$ is the linchpin of phagocytic cells because it enables them to be activated. Consequently, an increase in NF- $x \mathrm{~B}$ and/or its activators is observed in acute or chronic inflammation (Monaco et al., 2004; Song et al., 2009; Hajishengallis \& Chavakis, 2013). IkB- $\alpha$ inhibits $\mathrm{NF}-x \mathrm{~B}$ by masking the nuclear localisation signals of $\mathrm{NF}-x \mathrm{~B}$ proteins and sequestering them in an inactive state in the cytoplasm (Jacobs \& Harrison, 1998; Hinz, 2012). In addition, $\mathrm{I} x \mathrm{~B}-\alpha$ blocks the ability of $\mathrm{NF}-x \mathrm{~B}$ transcription factors to bind to deoxyribonucleic acid, which is necessary for the proper functioning of $\mathrm{NF}-x \mathrm{~B}$ (Verma et al., 1995; Huang, 2000; Birbach, 2002).

The significant increase in the gene expression of $I x B-a$ by PO diet and the non-significant decrease in the gene expression of $N F-x B$ show that PO diet protects the liver better against inflammation. The actions of PO on $N F-x B$ and $I x B-a$ genes could be explained by its high tocotrienol content (Sambanthamurthi et al., 2000; Lecerf, 2013). Indeed, tocotrienols have anti-inflammatory properties (Reiter et al., 2007; Yam et al., 2009) due to their involvement in inhibiting NF- $x \mathrm{~B}$ activation pathway (Ahn et al., 2007; Ng \& Ko, 2012). In-vitro studies with palm oil tocotrienols have shown its anti-inflammatory effects (Wu et al., 2008) and its ability to reduce cancer cell proliferation by inhibiting NF-kB activation pathway (Yap et al., 2008; Ji et al., 2015).

Studies in humans have shown that diets based on $\mathrm{PO}$ and $\mathrm{OO}$ do not promote inflammation at the plasma level (Teng et al., 2011; Tholstrup et al., 2011).

The search for macrophage infiltrations in liver with CD68 labeling (Fig. 1) showed a significant increase $(p<0.0001)$ in macrophage density with the OO diet compared to other diets. The significant increase of macrophage density in liver of the rats that consumed $\mathrm{OO}$ suggests that $\mathrm{OO}$ promoted inflammation in liver. This action of $\mathrm{OO}$ on liver could be explained by its high content of $\omega-6$ polyunsaturated fatty acids (PUFA). Indeed, according to many authors (Raphael \& Sordillo, 2013; Marion-Letellier et al., 2015) $\omega-6$ PUFA promote inflammation.

Despite its richness in saturated fatty acids, particularly palmitic acid, which is considered pro-inflammatory because it activates the $\mathrm{NF}-x \mathrm{~B}$ pathway (Ajuwon \&

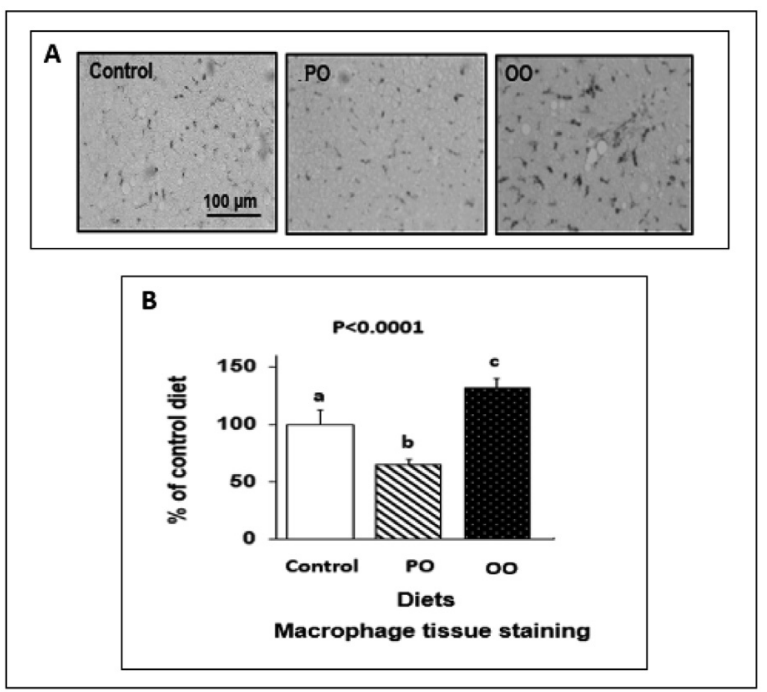

Figure 1. Effect of high dietary intake of palm olein and olive oil on hepatic macrophage infiltration.

(A) Histological section of liver ( $n=10-20 /$ rat) showing macrophage infiltrations after CD68 primary antibody marking (magnification x 200). (B) Quantity of macrophages $/ \mathrm{mm}^{2}$ of liver. Results were expressed as mean values \pm S.D., $n=7-8$ animals pergroup. Statistical analysis was based on one-way ANOVA followed by a Tukey Kramer multiple comparisons test. The limit of statistical significance was set at $p<0.05$. The group mean values with different letters $(a, b, c)$ are significantly different. CD68, Cluster of differentiation 68; PO, Palm olein; OO, Olive oil. 
Table 3. Blood oxidative stress parameters

Rats were fed their respective diet for 12 weeks. Results were expressed as mean values \pm S.D., $n=7-8$ animals per group. Statistical analysis was based on one-way ANOVA followed by a Tukey Kramer multiple comparisons test. The limit of statistical significance was set at $p<0.05$. The group mean values with different letters $(a, b, c)$ are significantly different.

\begin{tabular}{|c|c|c|c|c|}
\hline & Control & $\mathrm{PO}$ & $\mathrm{OO}$ & $p$ \\
\hline \multicolumn{5}{|l|}{ Antioxidant system } \\
\hline $\mathrm{SOD}(\mathrm{IU} / \mathrm{mL})$ & $324 \pm 15^{a}$ & $296 \pm 23^{b}$ & $326 \pm 18^{a}$ & 0.0108 \\
\hline GPx (IU/mL) & $14.4 \pm 3.3$ & $15.9 \pm 4.4$ & $13.9 \pm 1.4$ & NS \\
\hline \multicolumn{5}{|l|}{ Oxidation products } \\
\hline Thiol groups $(\mu M)$ & $112 \pm 52$ & $124 \pm 49$ & $111 \pm 44$ & NS \\
\hline TBARS $(\mu \mathrm{M})$ & $5.12 \pm 0.86$ & $5.26 \pm 1.04$ & $4.79 \pm 0.88$ & NS \\
\hline 15-F2t-isoprostane (AU) & $53 \pm 16^{a}$ & $44 \pm 06^{a b}$ & $37 \pm 06^{b}$ & 0.0167 \\
\hline
\end{tabular}

AU, arbitrary Unit; GPx, Glutathione peroxidase; PO, Palm olein; SOD, Superoxide dismutase; TBARS, Thiobarbituric acid reactive substances.

Spurlock, 2005; Laine et al., 2007), the results of this study and data from the literature show that PO has anti-inflammatory properties due to its high tocotrienol content.

\section{Effects of diets on antioxidant status}

In blood, SOD was significantly reduced $(p=0.0108)$ with PO diet compared to other diets. None of the diets resulted in a significant increase in oxidation products (Table 3). Concerning oxidation products, compared to the control diet, PO diet resulted in a non-significant increase of thiol groups by $10 \%$ and a non-significant decrease of $15-\mathrm{F} 2 \mathrm{t}$-isoprostane by $17 \%$. Compared to the control diet, $\mathrm{OO}$ diet has favoured a decrease of $1 \%$ of thiol groups, a decrease of $7 \%$ of TBARS and a significant decrease $(p=0.0167)$ of $15-\mathrm{F} 2 \mathrm{t}$-isoprostane of $31 \%$ (Table 3).

In liver, no significant differences were observed between diets with regard to their effects on oxidative stress parameters (Table 4). Concerning oxidation products, the level of thiol groups showed a non-significant tendency to increase $(p=0.0779)$ with PO $(+11 \%)$ and
OO $(+5 \%)$ compared to the control diet (Table 4$)$. The study of the expression of genes involved in the antioxidant system showed a non-significant tendency to increase $(\phi=0.0696) \mathrm{Nrf} 2$ gene with $\mathrm{OO}$ diet $(+35 \%)$ and PO diet $(+9 \%)$ compared to the control diet. The gene expression of NQO-1, HO-1 and GCLC was not modified in any diet (Table 4).

Thiols play a very important «buffer» role in the body. In the event of severe oxidative stress, thiols restore the «redox» balance (oxidation/reduction balance) by eliminating free radicals (Ferrer-Sueta et al., 2011). PO diet effectively protects liver against free radicals because it promotes an increase in plasma and liver thiols. Moreover, no diet has led to a significant decrease in the level of plasma and liver thiol groups. This suggests that no diet has favoured oxidative stress, as only the collapsed thiol levels objectivise old and/or chronic oxidative stress (Musaogullari \& Chai, 2020).

Lipoperoxidation was assessed by the determination of blood and liver TBARS and plasma 15-F2t-isoprotane. No diet resulted in a significant increase in these parameters compared to the control diet. Since only an

\section{Table 4. Liver oxidative stress parameters}

Rats were fed their respective diet for 12 weeks. Results were expressed as mean values \pm S.D., $n=7-8$ animals per group. Statistical analysis was based on one-way ANOVA followed by a Tukey Kramer multiple comparisons test. The limit of statistical significance was set at $p<0.05$. The group mean values with different letters $(a, b, c)$ are significantly different.

\begin{tabular}{|c|c|c|c|c|}
\hline & Control & $\mathrm{PO}$ & $\mathrm{OO}$ & $p$ \\
\hline \multicolumn{5}{|l|}{ Antioxidant system } \\
\hline $\mathrm{SOD}(\mathrm{U} / \mathrm{mg}$ protein) & $45.7 \pm 4.3$ & $43.9 \pm 3.3$ & $43.9 \pm 4.9$ & NS \\
\hline GPx (U/mg protein) & $6.69 \pm 0.51$ & $6.96 \pm 0.75$ & $6.52 \pm 0.72$ & NS \\
\hline Catalase (U/mg protein) & $725 \pm 57$ & $791 \pm 125$ & $787 \pm 53$ & NS \\
\hline $\mathrm{GSH}(\mathrm{nmol} / \mathrm{g} w \mathrm{w})$ & $126 \pm 16$ & $140 \pm 16$ & $122 \pm 18$ & NS \\
\hline GSH/GSSG & $4.91 \pm 0.34$ & $5.02 \pm 0.18$ & $4.96 \pm 0.46$ & NS \\
\hline Nrf2 (qPCR) & $1.00 \pm 0.24^{\mathrm{a}}$ & $1.09 \pm 0.21$ ba & $1.35 \pm 0.39 \mathrm{~b}$ & 0.0696 \\
\hline NQO-1 (qPCR) & $1.00 \pm 0.57$ & $0.87 \pm 0.40$ & $1.14 \pm 0.60$ & NS \\
\hline $\mathrm{HO}-1$ (qPCR) & $1.00 \pm 0.62$ & $0.91 \pm 0.25$ & $0.81 \pm 0.25$ & NS \\
\hline GCLC (qPCR) & $1.00 \pm 0.42$ & $1.26 \pm 0.30$ & $1.44 \pm 0.42$ & NS \\
\hline \multicolumn{5}{|l|}{ Oxidation products } \\
\hline Thiol groups (nmol/mg protein) & $110 \pm 10^{\mathrm{a}}$ & $123 \pm 9^{b}$ & $116 \pm 11^{\mathrm{ab}}$ & 0.0779 \\
\hline TBARS (nmol/mg protein) & $99 \pm 20$ & $90 \pm 18$ & $83 \pm 12$ & NS \\
\hline
\end{tabular}

GCLC, Glutamate-cysteine ligase catalytic subunit; GPx, Glutathione peroxidase; GSH, Reduced glutathione; GSSG, Oxidized glutathione; HO-1, Heme oxygenase-1; Nrf2 (Nfe2I2), Nuclear factor-erythroid 2 related factor 2; NQO-1, NAD(P)H quinone dehydrogenase 1; qPCR, Quantitative-Polymerase chain reaction; PO, Palm olein; SOD,Superoxide dismutase; TBARS, Thiobarbituric acid reactive substances; ww, Wet weight. 
increase in these parameters indicates lipid oxidation by free radicals, we can say that $\mathrm{PO}$ and $\mathrm{OO}$ diets did not favour lipoperoxidation.

These results indicate that despite the significant decrease in SOD activity by PO diet compared to the control diet, PO diet does not favour oxidative stress compared to OO diet. This antioxidant power could be partly explained by the increase in the amount of thiols in the PO diet.

In addition, numerous studies argue in favour of the antioxidant power of palm oil. Selenium deficiency favours the reduction of GPx activity with the consequent occurrence of a significant oxidative stress, the source of many pathologies (Navarro-Alarcon \& Lopez-Martinez, 2000; Rayman, 2000). A study carried out in Côte d'Ivoire showed that subjects deficient in selenium and GPx, regular consumers of palm oil (crude or olein) had a good antioxidant status and did not present oxidative stress (Tiahou et al., 2004). In another study conducted on four varieties of palm oil from Côte d'Ivoire, Mondé and others (Mondé et al., 2011) showed that antioxidants in these different variants reduce LDL oxidation in vitro.

Palm oil owes its nutritional benefits, linked to its antioxidant power, to its «minor» components. In animals, numerous studies (Suarna et al., 1993; Azlina et al., 2005; Suzana et al., 2005) have highlighted the antioxidant effects of palm oil tocotrienols. Coenzyme Q10 (ubiquinone), a natural coenzyme of palm oil, is a powerful free radical scavenger (Niklowitz et al., 2007) with ten times the antioxidant power of carotenoids and vitamin $\mathrm{E}(\mathrm{Ng}$ et al., 2006). Palm oil is the vegetable oil richest in tocotrienols (Sundram et al., 2003; Sen et al., 2010). Tocotrienols are powerful antiradical agents with a proven cardioprotective role (Rooyen et al., 2008; Vasanthi et al., 2012; Wong \& Radhakrishnan, 2012).

Despite the loss of carotenoids (Lecerf, 2013) and micro-constituents such as flavonoids and phenolic acids during refining (Tan et al., 2001), PO still retains its antioxidant properties, as the results of this study show. This may be due to the fact that during refining, PO is enriched with tocotrienols (Sambanthamurthi et al., 2000; Lecerf, 2013), which are powerful free radical scavengers.

\section{CONCLUSION}

This study showed that PO decreases SOD activity compared to OO while OO increases macrophagic infiltration in the liver. PO consumption does not promote inflammation and oxidative stress.

\section{Acknowledgements}

We thank Dr Jonas Laget for his help during the dissection of the rats. We thank SANIA company for providing us with palm olein.

\section{Conflicts of Interest}

The authors declare that there is no conflict of interest regarding publication of this article.

\section{REFERENCES}

Ahn KS, Sethi G, Krishnan K, Aggarwal BB (2007) Gamma-tocotrienol inhibits nuclear factor-kappaB signaling pathway through inhibition of receptor-interacting protein and TAK1 leading to suppression of antiapoptotic gene products and potentiation of apoptosis. J Biol Chem 282: 809-820. https://doi.org/10.1074/jbc.M610028200

Ajuwon KM, Spurlock ME (2005) Palmitate activates the NF-kap$\mathrm{paB}$ transcription factor and induces IL-6 and TNFalpha expres- sion in 3T3-L1 adipocytes. I Nutr 135: 1841-1846. https://doi. org/10.1093/jn/135.8.1841

Assy N, Nassar F, Nasser G, Grosovski M (2009) Olive oil consumption and non-alcoholic fatty liver disease. World J Gastroenterol 15: 1809-1815. https://doi.org/10.3748/wjg.15.1809

Birbach A, Gold P, Binder BR, Hofer E, de Martin R, Schmid JA (2002) Signaling molecules of the NF-kappa B pathway shuttle constitutively between cytoplasm and nucleus. I Biol Chem 277: 1084210851. https://doi.org/10.1074/jbc.M112475200

Bradford MM (1976) A rapid and sensitive method for the quantitation of microgram quantities of protein utilizing the principle of proteindye binding. Anal Biochem 72: 248-254. https://doi.org/10.1006/ abio.1976.9999

Čmolík J, Pokorný J (2000) Physical refining of edible oils. Eur J Lipid Sci Technol 102: 472-486. https://doi.org/10.1002/14389312(200008)102

Coudray C, Fouret G, Lambert K, Ferreri C, Rieusset J, BlachnioZabielska A, Lecomte J, Ebabe ER, Badia E, Murphy MP, FeilletCoudray C (2016) A mitochondrial-targeted ubiquinone modulates muscle lipid profile and improves mitochondrial respiration in obesogenic diet-fed rats. Br J Nutr 115: 1155-1166. https://doi. org/10.1017/S0007114515005528

Covas Mi R-GV, de la Torre R, Kafatos A, Lamuela-Ravento's RM, Osada J (2006) Minor components of olive oil: evidence to date of health benefits in humans. Nutr Rev 64: 20e30. https://doi. org/10.1111/j.1753-4887.2006.tb00260.x

Djohan YF, Badia E, Bonafos B, Fouret G, Lauret C, Dupuy AM, Pinot E, Sutra T, Gaillet S, Lambert K, Raynaud F, Gayrard N, Jover B, Monde AA, Cristol JP, Coudray C, Feillet-Coudray C (2019) High dietary intake of palm oils compromises glucose tolerance whereas high dietary intake of olive oil compromises liver lipid metabolism and integrity. Eur J Nutr 58: 3091-3107. https://doi. org/10.1007/s00394-018-1854-3

Edem DO (2002) Palm Oil: Biochemical, physiological, nutritional, hematological, and toxicological aspects: A review. Plant Foods Hum Nutr 57: 319-341. https://doi.org/10.1023/a:1021828132707

Fattore E, Bosetti C, Brighenti F, Agostoni C, Fattore G (2014) Palm oil and blood lipid-related markers of cardiovascular disease: A systematic review and meta-analysis of dietary intervention trials. Am J Clin Nutr 99: 1331-1350. https://doi.org/10.3945/ajcn.113.081190

Faure P, Lafond J (1995) Measurement of plasma sulfhydryl and carbonyl groups as a possible indicator of protein oxidation. In Analysis of free radicals in biological systems. Favier A, Cadet J, Kalyanaraman B, Fontecave M, Pierre J, eds, pp 237-248. Birkhauser Verlag, Basel https://doi.org/10.1007/978-3-0348-9074-8_17

Ferrer-Sueta G, Manta B, Botti H, Radi R, Truijllo M, Denicola A (2011) Factors affecting protein thiol reactivity and specificity in peroxide reduction. Chem Res Toxicol 24: 434-450. https://doi. org/10.1021/tx100413v

Flohe L, Gunzler WA (1984) Assays of glutathione peroxidase. Methods Enzymol 105: 114-121. https://doi.org/10.1016/s00766879(84)05015-1

Hajishengallis G, Chavakis T (2013) Endogenous modulators of inflammatory cell recruitment. Trends Immunol 34: 1-6. https://doi. org/10.1016/j.it.2012.08.003

Hinz M, Arslan SC, Scheidereit C (2012) It takes two to tango: IkBs, the multifunctional partners of NF-kB. Immunol Rev 246: 59-76. https://doi.org/10.1111/j.1600-065X.2012.01102.x

Huang TT, Kudo N, Yoshida M, Miyamoto S (2000) A nuclear export signal in the N-terminal regulatory domain of IkappaBalpha controls cytoplasmic localization of inactive NF-kappaB/IkappaBalpha complexes. Proc Natl Acad Sci USA 97: 1014-1019. https://doi. org/10.1073/pnas.97.3.1014

Jacobs MD, Harrison SC (1998) Structure of an I kappa B alpha/NFkappa B complex. Cell 95: 749-758. https://doi.org/10.1016/s00928674(00)81698-0

Ji X, Usman A, Razalli NH, Sambanthamurthi R, Gupta SV (2015) Oil palm phenolics (OPP) inhibit pancreatic cancer cell proliferation via suppression of NF-xB pathway. Anticancer Res 35: 97-106

Laine PS, Schwartz EA, Wang Y, Zhang WY, Karnik SK, Musi N, Reaven PD (2007) Palmitic acid induces IP-10 expression in human macrophages via NF-kappaB activation. Biochem Biophys Res Commun 358: 150-155. https://doi.org/10.1016/j.bbrc.2007.04.092

Lecerf JM (2013) L'huile de palme: aspects nutritionnels et métaboliques. Rôle sur le risque cardiovasculaire. OCL 20: 147-159. https://doi.org/10.1051/ocl.2013.0507

Mancini A, Imperlini E, Nigro E, Montagnese C, Daniele A, Orrù S, Buono P (2015) Biological and nutritional properties of palm oil and palmitic acid: Effects on health. Molecules 20: 17339-17361. https://doi.org/10.3390/molecules200917339

Marion-Letellier R, Savoye G, Ghosh S (2015) Polyunsaturated fatty acids and inflammation. IUBMB Life 67: 659-667. https://doi. org/10.1002/iub.1428

Marklund S (1976) Spectrophotometric study of spontaneous disproportionation of superoxide anion radical and sensitive direct assay for superoxide dismutase. J Biol Chem 251: 7504-7507 
Mas E, Michel F, Guy A, Bultel V, Falquet Y, Chardon P, Rossi JC, Cristol JP, Durand T (2008) Quantification of urinary F2-isoprostanes with 4(RS)-F4tneuroprostane as an internal standard using gas chromatographymass spectrometry Application to polytraumatized patients. J Chromatogr B Analyt Technol Biomed Life Sci 872: 133-140. https://doi.org/10.1016/j.jchromb.2008.07.037

Mba OI, Dumont MJ, Ngadi M (2015) Palm Oil: Processing, characterization and utilization in the food industry - A review. Food Biosci 10: 26-41. https://doi.org/10.1016/j.fbio.2015.01.003

Monaco C, Andreakos E, Kiriakidis S, Mauri C, Bicknell C, Foxwell B, Cheshire N, Paleolog E, Feldmann M (2004) Canonical pathway of nuclear factor kappa B activation selectively regulates proinflammatory and prothrombotic responses in human atherosclerosis. Proc Natl Acad Sci USA 101: 5634-5639. https://doi.org/10.1073/ pnas.0401060101

Mondé AA, Carbonneau MA, Michel F, Laure C, Diabate S, Konan E, Sess D, Cristol JP (2011) Potential health implication of in vitro human low-density lipoprotein-vitamin e oxidation modulation by polyphenols derived from Côte d'Ivoire's oil palm species. J Agric Food Chem 59: 9166-9171. https://doi.org/10.1021/jf201658g

Musaogullari A, Chai YC (2020) Redox regulation by protein sglutathionylation: From molecular mechanisms to implications in health and disease. Int J Mol Sci 21: 8113. https://doi.org/10.3390/ ijms21218113.

Navarro-Alarcon M, Lopez-Martinez MC (2000) Essentiality of selenium in human body: relationship with different diseases. Sc Total Envir 249: 347-371. https://doi.org/10.1016/s0048-9697(99)00526-4

$\mathrm{Ng} \mathrm{LT}$, Ko HJ (2012) Comparative effects of tocotrienol-rich fraction, $\alpha$-tocopherol and $\alpha$-ocopheryl acetate on inflammatory mediators and nuclear factor kappa $\mathrm{B}$ expression in mouse peritoneal macrophages. Food Chem 134: 920-925. https://doi.org/10.1016/j.foodchem.2012.02.206

Ng MH, Choo YM, Ma AN, Chuah CH, Hashim MA (2006) Separation of coenzyme Q10 in palm oil by supercritical fluid chromatography. Am J Appl Sci 3: 1929-1932. https://doi.org/10.3844/ ajassp.2006.1929.1932

Niklowitz P, Sonnenschein A, Janetzky B, Andler W, Menke T (2007) Enrichment of coenzyme Q10 in plasma and blood cells: Defense against oxidative damage. Int J Biol Sci 3: 257-262. https://doi. org/10.7150/ijbs.3.257

Odia OJ, Ofori S, Maduka O (2015) Palm oil and the heart: A review. World J Cardiol 26: 144-149. https://doi.org/10.4330/wic.v7.i3.144

Ong AS, Goh SH (2002) Palm oil: A healthful and cost-effective dietary component. Food Nutr Bull 23: 11-22. https://doi. org/10.1177/156482650202300102

Owen RW, Mier W, Giacosa A, Hull WE, Spiegelhalder B, Bartsch H (2000) Phenolic compounds and squalene in olive oils: the concentration and antioxidant potential of total phenols, simple phenols, secoiridoids, lignansand squalene. Food Chem Toxicol 38: 647e59. https://doi.org/10.1016/s0278-6915(00)00061-2

Perez-Jimenez F, Alvarez de Cienfuegos G, Badimon L, Barja G, Battino M, Blanco A (2005) International conference on the healthy effect of virgin olive oil. Eur J Clin Invest 35: 421e4. https://doi. org/10.1111/j.1365-2362.2005.01516.x

Raphael W, Sordillo LM (2013) Dietary polyunsaturated fatty acids and inflammation: The role of phospholipid biosynthesis. Int I Mol Sci 22: 21167-21188. https://doi.org/10.3390/ijms141021167

Rayman MP (2000) The importance of selenium to human health. Lancet 356: 233-241. https://doi.org/10.1016/S0140-6736(00)02490-9

Reiter E, Jiang Q, Christen S (2007) Anti-inflammatory properties of alpha-and gamma-tocopherol. Mol Aspects Med 28: 668-691. https:// doi.org/10.1016/j.mam.2007.01.003

Rooyen JV, Esterhuyse AJ, Engelbrecht AM, Toit EF (2008) Health benefits of a natural carotenoid rich oil: A proposed mechanism of protection against ischemia/reperfusion injury. Asia Pac J Clin Nutr 17: 316-319. PMID: 18296367

Sambanthamurthi R, Sundram K, Tan Y (2000) Chemistry and biochemistry of palm oil. Prog Lipid Res 39: 507-558. https://doi. org/10.1016/s0163-7827(00)00015-1

Sen CK, Khanna S, Roy S (2007) Tocotrienols in health and disease: The other half of the natural vitamin E family. Mol Asp Med 28: 692-728. https://doi.org/10.1016/j.mam.2007.03.001
Sen CK, Rink C, Khanna S (2010) Palm oil-derived natural vitamin e alpha-tocotrienol in brain health and disease. $J$ Am Coll Nutr 29: 314S-323S. https://doi.org/10.1080/07315724.2010.10719846

Song XQ, Lv LX, Li WQ, Hao YH, Zhao JP (2009) The interaction of nuclear factor-kappa B and cytokines is associated with schizophrenia. Biol Psychiatry 65: 481-488. https://doi.org/10.1016/j.biopsych.2008.10.018

Suarna C, Hood RL, Dean RT, Stocker R (1993) Comparative antioxidant activity of tocotrienols and other natural lipid-soluble antioxidants in a homogeneous system, and in rat and human lipoproteins. Biochim Biophys Acta 1166: 163-170. https://doi.org/10.1016/00052760(93)90092-n

Sunderman FW Jr, Marzouk A, Hopfer SM, Zaharia O, Reid MC (1985) Increased lipid peroxidation in tissues of nickel chloridetreated rats. Ann Clin Lab Sci 15: 229-236. PMID: 3994292

Sundram K, Sambanthamurthi R, Tan YA (2003) Palm fruit chemistry and nutrition. Asia Pac J Clin Nutr 12: 355-362. PMID: 14506001

Suzana M, Suhana M, Zalinah A, Gapor MT, Wan Ngah WZ (2005) Comparative effects of alpha-tocopherol and gamma-tocotrienol on lipid peroxidation status in Hep G2 cell line transfected with CYP2E1 gene. Eur J Sci Res 7: 41-56

Tan YA, Sundram K, Sambanthamurthi R (2001) Water soluble phenolics from the palm oil industry. In Biologically-active Phytochemicals in Food: Analysis, Metabolism, Bioavailability and Function. Pfannhauser W, Fenwick GR, Khokhar S, eds. 269: 548-551. Cambridge: The Royal Society of Chemistry

Tarmizi AHA, Lin SW (2008) Quality assessment of palm products upon prolonged heat treatment. J Oleo Sci 57: 639-648. https://doi. org/10.5650/jos.57.639

Teng KT, Nagapan G, Cheng HM, Nesaretnam K (2011) Palm olein and olive oil cause a higher increase in postprandial lipemia compared with lard but had no effect on plasma glucose, insulin and adipocytokines. Lipids 46: 381-388. https://doi.org/10.1007/ s11745-010-3516-y

Tholstrup T, Hjerpsted J, Raff M (2011) Palm olein increases plasma cholesterol moderately compared with olive oil in healthy individuals. Am J Clin Nutr 94: 1426-1432. https://doi.org/10.3945/ ajcn.111.018846

Tiahou G, Maire B, Dupuy A, Delage M, Vernet M, Mathieu-Daude J, Michel F, Sess E, Cristol J (2004) Lack of oxidative stress in a selenium deficient area in Ivory Coast: Potential nutritional antioxidant role of crude palm oil. Eur J Nutr 43: 367-374. https://doi. org/10.1007/s00394-004-0484-0

USDA (2021) Foreign Agricultural Service, Oilseeds: Word Markets and Trade. $39 \mathrm{p}$

Valko M, Rhodes CJ, Moncol J, Izakovic M, Mazur M (2006) Free radicals, metals and antioxidants in oxidative stress-induced cancer. Chem Biol Interact 160: 1-40. https://doi.org/10.1016/j. cbi.2005.12.009

Vasanthi HR, Parameswari RP, Das DK (2012) Multifaceted role of tocotrienols in cardioprotection supports their structure: function relation. Genes Nutr 7: 19-28. https://doi.org/10.1007/s12263-0110227-9

Verma IM, Stevenson JK, Schwarz EM, Van Antwerp D, Miyamoto S (1995) Rel/NF-kappa B/I kappa B family: intimate tales of association and dissociation. Genes Dev 9: 2723-2735. https://doi. org/10.1101/gad.9.22.2723

Wong RSY, Radhakrishnan AK (2012) Tocotrienol research: past into present. Nutr Rev 70: 483-490. https://doi.org/10.1111/j.17534887.2012.00512.x

Wu SJ, Liu PL, Ng LT (2008) Tocotrienol-rich fraction of palm oil exhibits anti-inflammatory property by suppressing the expression of inflammatory mediators in human monocytic cells. Mol Nutr Food Res 52: 921-929. https://doi.org/10.1002/mnfr.200700418

Yam ML, Abdul Hafid SR, Cheng HM, Nesaretnam K (2009) Tocotrienols suppress proinflammatory markers and cyclooxygenase-2 expression in RAW264.7 macrophages. Lipids 44: 787-797. https:// doi.org/10.1007/s11745-009-3326-2

Yap WN, Chang PN, Han HY (2008) Gamma-tocotrienol suppresses prostate cancer cell proliferation and invasion through multiple-signalling pathways. Br J Cancer 99: 1832-1841. https://doi. org/10.1038/sj.bjc.6604763 